\title{
RUBEM BRAGRA: INTERTEXTUALIDADE E SOCIEDADE
}

Tchiago Inague Rodrigues ${ }^{1}$, Édima de Souza Mattos ${ }^{2}$

${ }^{1}$ Mestrando em Letras - Literatura e Vida Social - UNESPIASSIS, txiinague@gmail.com. ${ }^{2}$ Docente do Curso de Jornalismo da UNOESTE. Doutoranda em Letras - Literatura e Vida Social - UNESPIASSIS. edima@unoeste.br

\section{RESUMO}

É importante pesquisar as relações intertextuais e dialógicas das diferentes manifestações estético-literárias entre si, notadamente o texto jornalístico e a literatura. Este artigo tem como objeto de estudo as crônicas de Rubem Braga, jornalista e escritor que se destacou por produzir exclusivamente textos deste gênero híbrido. O corpus eleito da pesquisa é a crônica O jovem casal (1953), do qual é feita uma análise críticointerpretativa. Destaca o modo como foram expostas as questões sociais da época, revelando o papel crítico do intelectual frente à sociedade de seu tempo.

Palavras-chave: Rubem Braga. Literatura e Jornalismo. Crônicas.

\section{RUBEM BRAGA: INTERTEXTUALITY AND SOCIETY}

\section{ABSTRACT}

It is important to research the intertextual and dialogical relations of different literary-aesthetic manifestation between them, notably the journalistic text and the literature.This article has as object of study the chronicles of Rubem Braga, jornalist and writer who was noted for only produce texts of this hybrid genre. The elected body of the research is the chronicle "O jovem casal" (1953), which is made a critical-interpretive analysis. Highlights how the social issues of the period were exposed, revealing the critical role of the intellectual in front of his time's society.

Keywords: Rubem Braga. Literature and Journalism. Chronicles. 


\section{INTRODUÇÃO}

É mister pesquisar as relações intertextuais e dialógicas das diferentes manifestações estético-literárias entre si, notadamente o texto jornalístico e a literatura. Considerando que em literatura "a vida pulsa" é de primordial relevância demonstrar a tênue separação entre ficção e factualidade. $O$ texto jornalístico, como meio de comunicação social na modalidade textual da crônica possui conectividade com a literatura, por meio da linguagem e da catarse que exerce sobre o leitor. Esta catarse conduz-nos a compreender melhor o contexto histórico-social e político que permeia uma época, como também, a trama que são as relações interpessoais.

Para referendar essa simbiose entre texto literário e texto jornalístico, é exposta a seguinte citação:

\begin{abstract}
Tanto na história como na ficção toda palavra alude à realidade, mas não é realidade. A ficção e a história, então, podem considerar-se metáforas da realidade: uma, a história, lutando por afirmar seu princípio de verdade; a outra, por impor seu princípio de ilusão. Mas as duas é preciso eleger, reconstruir, imaginar. (MARTINEZ apud LIMA, [s/d], p. 20).
\end{abstract}

É com esta preocupação que esta pesquisa teve como enfoque, a intertextualidade entre a literatura e o jornalismo sobre a ótica das crônicas de Rubem Braga. Para tanto, é relevante destacar que o termo intertextualidade é oriundo de Julia Kristeva que se baseou no dialogismo de Bakhtin.

\section{RUBEM BRAGA: HISTÓRIA E VIDA}

O escritor e jornalista, Rubem Braga, nasceu em Cachoeiro de Itapemirim, Espírito Santo no dia 12 de janeiro de 1913. No ano de 1932 concluiu o curso de Direito em Belo Horizonte, Minas Gerais, depois de ter participado como repórter dos Diários Associados, na cobertura da Revolução Constitucionalista em
Minas Gerais. Casou-se em 1936 com Zora Seljan Braga, que mais tarde desquitou e teve como fruto desta relação, seu único filho, Roberto Braga.

Em 1945 foi correspondente de guerra na Itália, pelo Diário Carioca. Desta experiência, surgiu o livro Com a FEB na Itália. Regressando ao Brasil, morou em algumas capitais, mas se estabeleceu definitivamente no Rio de Janeiro. No ano de 1961 o escritor é nomeado embaixador do Brasil em Marrocos.

Rubem Braga em parceria com Fernando Sabino e Otto Lara Resende fundou, em 1968, a Editora Sabiá, responsável pelo lançamento no Brasil de escritores como Gabriel Garcia Márquez, Pablo Neruda e Jorge Luis Borges.

O autor faleceu na cidade do Rio de Janeiro, em 19 de dezembro de 1990, deixando uma vasta coletânea de crônicas publicadas em diversos livros.

O escritor, em questão, sempre foi reservado; ele mesmo se dizia "um homem tímido" (BRAGA, 2008, p. 72), mas ao estabelecer o vínculo com o leitor por meio das crônicas, conseguia sair de sua individualidade, promovendo contato com a vida e com a sociedade. Ao fazer isso, suas crônicas "ganham a dimensão de lirismo reflexivo e participante da imensa dor coletiva" (SÁ, 1999, p. 14).

Antonio Candido, no ensaio $A$ vida ao résdo-chão, expõe o importante papel que a crônica, mesmo sendo um gênero menor, exerce, devendo ser valorizada, já que "quando passa do jornal ao livro, nós verificamos meio espantados que a sua durabilidade pode ser maior do que ela própria pensava" (1992, p. 14-15).

Há de se considerar, também, que ao examinar as principais correntes filosóficas que permeiam o pensamento humano e são expressas pela literatura, não é difícil cruzá-las com o texto jornalístico que noticia fatos subjacentes a essas correntes. 


\section{AS CRÔNICAS}

As preocupações históricas ou éticopolíticas apresentadas nas crônicas de Rubem Braga foram analisadas pela crítica existencialista de pensadores como Jean Paul Sartre, Karl Marx dentre outros, os quais veem a literatura como um veículo que revela o mundo por meio das palavras. Isso inclui a ação social, os compromissos éticos e políticos que permeiam uma sociedade.

Deste modo, foi pesquisado o Rubem Braga literário, preocupado com essas questões existencialistas de seu tempo, as quais são expressas pelas crônicas que, também, são peculiaridades do jornalismo impresso.

O jornalismo e a literatura se "casam" há longa data. Numa retrospectiva histórica, facilmente descobre-se que por intuição, sem preocupação metodológica, que os jornalistas possuíam uma tendência a se inspirarem na arte literária para expressarem a factualidade. O caminho inverso também é verdadeiro. Há uma miríade de autores exemplificando que não há barreira intransponível entre o jornalismo, enquanto relato do real, e a literatura trabalhando com a ficção, a linguagem referencial e literária se entrelaçam.

O jornalismo, no seu processo de informar, fascina os leitores, com uma simples arma: a escrita, como afirma Clóvis Rossi (1994, p. 7).

Jornalismo, independentemente de qualquer definição acadêmica, é uma fascinante batalha pela conquista das mentes e corações de seus alvos: leitores, telespectadores ou ouvintes. Uma batalha geralmente sutil e que usa uma arma de aparência extremamente inofensiva: a palavra, acrescida, no caso da televisão, de imagens. Mas uma batalha nem por isso menos importante do ponto de vista política e social, o que justifica e explica as imensas verbas canalizadas por governos, partidos, empresários e entidades diversas para o que se convencionou chamar veículos de comunicação de massa.
A pesquisa não teve a pretensão de demonstrar conclusões definitivas, mas sim suscitar o interesse por este recorte na produção deste autor atemporal Rubem Braga.

As crônicas de Rubem Braga conduzem o leitor a uma incursão no mundo do real com nuances do texto ficcional.

A fim de comparar a linguagem factual do jornalismo com a ficcional do texto literário, fez-se necessário resgatar o conceito de literatura e de crônica. Para isso, foram consultados teóricos renomados como Antônio Candido, Afrânio Coutinho, Edvaldo Pereira Lima e Jorge de Sá.

O corpus da pesquisa foi a crônica de Rubem Braga, O jovem casal (1953), que passou por uma análise crítico-descritiva quanto à linguagem midiática, literária e linguistas elencadas na bibliografia.

Foi utilizado o método dedutivo, com abordagem da pesquisa teórico-investigativa e analítica.

Após a leitura do corpus $O$ jovem casal (crônica publicada em jornal em 1953) e a observação dos conceitos de autores que tratam da abordagem da pesquisa foi realizada a análise em consonância entre as duas linguagens; a literária e jornalística em trechos, expressões, contextualização e formas de abordagem dos assuntos enfocados pelo autor.

Sobre a linguagem do jornalismo e o seu "modus operandi", pode-se dizer: Trata-se, portanto de um processo
contínuo, ágil, veloz, determinado pela
atualidade. O fio de ligação entre
emissor e receptor é o conjunto dos
fatos que estão acontecendo. O ponto
de tensão entre ambos está na
diferença entre o que a coletividade
gostaria de conhecer e o que a
instituição jornalística quer fazer saber.
A permanência da relação social está
em íntima dependência do equilíbrio
que se estabelece entre os interesses
da instituição e as expectativas da
coletividade. O que pressupõe
velocidade, credibilidade e abrangência.
(MELO, 1994, p. 15). 
A crônica O jovem casal (abril de 1953), evidenciou as discrepâncias socioculturais e econômicas que existem entre as pessoas de um mesmo país, num mesmo estado e na mesma cidade. Isso pode ser exposto no fragmento em que o jovem casal, após perderem o bonde, parados, esperando a próxima condução, em uma esquina, são surpreendidos por outro casal num carro conversível que para na rua, esperando o semáforo abrir:

[...] o senhor meio calvo dizia alguma coisa sôbre anéis, e no momento do carro partir com um arranco macio e poderoso ouviram que a mulherzinha dizia: "se elê deixar aquêle por quinze contos, eu fico.

Quinze contos - isso entrou dolorosamente pelos ouvidos do rapaz, parece que foi bater como um sôco, em seu estômago mal alimentado -, quinze contos, meses e meses de pensão! Então olhou a mulher e achou-a tão linda e triste com sua blusinha branca, tão frágil, tão jovem e tão querida, que sentiu os olhos arderem de vontade de chorar de humilhação por ser tão pobre [...] (BRAGA, 1964, p. 37).

A desigualdade, mesmo em uma crônica, sensibiliza o ser humano, provoca a catarse, o leitor entra no universo do narrador. Há o jogo entre a ficção e a realidade. Pois, o país na década de cinqüenta, apresentava índices terríveis de desigualdade social.

É possível identificar elementos descritivos presentes na crônica, sobre o estado de miséria da pensão em que o casal vivia. $O$ narrador vê isso de forma nua e crua:

\begin{abstract}
E havia as pulgas; havia a falta de água, e quando havia água, a fila dos hóspedes no corredor, diante da porta do chuveiro. Havia as instalações que sempre cheiravam mal, o papel da parede amarelado e feio, as duas velhas gordas, pintadas, da mesinha ao lado, que Ihe tiravam o apetite para a mesquinha comida da pensão. Tôda a tristeza, tôda a mediocridade, tôda a feiúra duma vida estreita onde o maugôsto atroz e pretensioso da classe média se juntava à minuciosa ganância pessoal (BRAGA, 1964, p. 36).
\end{abstract}

Feita a breve análise, é possível notar que até mesmo a crítica social é exposta através do lirismo, evidenciado por meio da captação de momentos do cotidiano repleto de sentimento e emoção, sendo o autor "seguramente o mais subjetivo dos cronistas brasileiros. E o mais lírico. Muitas de suas crônicas são poemas em prosa" (COUTINHO, 1999, p. 133).

Com o ar de quem está simplesmente
divagando, e em tom de conversa fiada,
mas que não falta boa dose de humor,
ele vai discorrendo naturalmente sobre
um fato e outro, transmitindo
impressões e comentários, e vai
mergulhando a fundo nos sentimentos
dos homens, chegando a tecer muitas
críticas sociais contundentes.
(COUTINHO, 2006, p. 54, grifo nosso).

\section{CONCLUSÃO}

O trabalho buscou mostrar o engajamento social do escritor através das crônicas, bem como a intertextualidade que há entre o gênero jornalístico e literário.

É importante ressaltar que as crônicas, pelo fato de serem publicadas em jornais, (são textos menos densos, breves) são lidas, "consumidas" de modo imediato. No entanto, o objeto de estudo, mesmo redigido no meio do século passado, continua se firmando na atualidade do início do século $\mathrm{XXI}$, pois não 0 impediu que mostrasse, por meio do lírico reflexivo, as misérias escamoteadas, presentes na sociedade brasileira.

Essa transposição, contextualização para a sociedade atual, faz adaptações no que diz respeito aos meios de transporte (se antes era bonde, hoje é o metrô, ônibus), por meio da denominação da moeda pátria, troque réis por reais, através das normas ortográficas, pôde e o pode, enfim, o que muda, atualiza são apenas os objetos inseridos na história, ou seja, adotam um novo corpo, ganham outra forma.

No entanto, ao contrário das formas, que são moldadas, aprimoradas, a essência continua atual na crônica de 1953, pois as personagens são outras, mas continuam sensíveis, não se vive sobre o regime de exceção, mas a dominação sobre o homem permanece. As gírias são outras, 
mas a linguagem coloquial vive, e o principal: a desigualdade social que se eterniza na cronologia humana.

Quanto à presença da linguagem coloquial, pode-se destacar, entre outras, as expressões: "gente pendurada nos estribos", "Viu aquela vaca dizendo que vai comprar um anel de quinze contos?".

Trazer à baila esta crônica mostra 0 compromisso político-social que Rubem Braga teve com a sociedade ao esmiuçá-la, através dos problemas vigentes à sua época que são contextualizados e tidos como os mesmos em nosso tempo.

Para referendar as conclusões citadas, apresentamos a crônica, na íntegra.

\section{Anexo}

\section{O jovem casal (Rubem Braga)}

Estavam esperando o bonde e fazia muito calor. Veio um bonde, mas estava tão cheio, com tanta gente pendurada nos estribos que ela apenas deu um passo à frente, êle esboçou com o braço o gesto de quem vai pegar um balaústre - mas desistiram.

Um homem com uma carrocinha de pão obrigou-os a recuar para perto do meio-fio; depois o negrinho de uma lavanderia passou com a bicicleta tão junto que um vestido esvoaçante bateu na cara do rapaz.

Ela se queixou de dor de cabeça; êle sentia uma dor de dente não muito forte, mas enjoada e insistente, mas preferiu não dizer nada. Ano e meio casados, tanta aventura sonhada, e estavam tão mal naquele quarto de pensão do Catete, muito barulhento: "Lutaremos contra tudo" - havia dito - e êle pensou com amargor que estavam lutando apenas contra as baratas, as horríveis baratas do velho sobradão. Ela com um gesto de susto e nojo se encolhia a um canto ou saía para o corredor - êle, com repugnância, ia matar o bicho; depois, com mais desgôsto ainda, jogá-lo fora.

E havia as pulgas; havia a falta de água, e quando havia água, a fila dos hóspedes no corredor, diante da porta do chuveiro. Havia as instalações que cheiravam mal, o papel da parede amarelado e feio, as duas velhas gordas, pintadas, da mesinha ao lado, que lhe tiravam o apetite para a mesquinha comida da pensão. Tôda a tristeza, tôda a mediocridade, tôda a feiúra duma vida estreita, onde o mau-gôsto atroz e pretensioso da classe média se juntava à minuciosa ganância comercial - um ôvo era "extraordinário", quando êles pediam dois ovos a dona da pensão olhava com raiva, estavam atrasados dias no pagamento.

Passou um ônibus enorme, parou logo adiante abrindo com ruído a porta, num grande suspiro de ar comprimido, e ela nem sequer olhou o ônibus, era tão mais caro. Êle teve um ímpeto, segurou-a pelo braço disposto a fazer uma pequena loucura financeira - "vamos pegar o ônibus!". Mas o monstro se fechara e partira jogando-Ihes na cara um jato de fumaça ruim.

Êle então chegou mais perto dela - lá vinha outro bonde, não, mas aquêle não servia -, enlaçou-a pela cintura, depois ficou segurando seu ombro com um gesto de ternura protetora, disse-lhe vagas meiguices, ela apenas ficou quieta. "Está doendo muito a cabeça?" Ela disse que não. "Seu cabelo agora está mais bonito, meio queimado de sol." Ela sorriu levemente, mas de repente: "Ih, me esqueci da receita do médico", pediu-lhe a chave do quarto, êle disse que iria apanhar para ela, ela disse que não, ela iria; quando voltou, foi exatamente a tempo de perder um bonde vazio; os dois ficaram ali desanimados.

Então um grande carro conversível se deteve um instante perto dos dois, diante do sinal fechado. Lá dentro havia um casal, um sujeito meio calvo de ar importante na direção, uma mulherzinha muito pintada ao lado, sentiram o cheiro de seu perfume caro. A mulherzinha deuIhes um vago olhar, examinou um pouco mais detidamente a môça, correndo os olhos da cabeça até os sapatos pobres - enquanto o senhor meio calvo dizia alguma coisa sobre anéis, e no momento do carro partir com um arranco macio e poderoso ouviram que a mulherzinha dizia: "se elê deixar aquele por quinze contos, eu fico."

Quinze contos - isso entrou dolorosamente pelos ouvidos do rapaz, parece que foi bater, como um sôco, em seu estômago mal alimentado - quinze contos, meses e meses de pensão! Então olhou a mulher e achou-a tão linda e triste com sua blusinha branca, tão frágil, tão jovem e tão querida, que sentiu os olhos arderem de vontade de chorar de humilhação por ser tão pobre; disse: "Viu aquela vaca dizendo que vai comprar um anel de quinze contos?" Vinha o bonde.

Abril, 1953

\section{REFERÊNCIAS}

BRAGA, R. A cidade e a roça e três primitivos. 3.ed. Rio de Janeiro: Editora Sabiá Limitada, 1964.

BRAGA, R. 200 crônicas escolhidas. 29.ed. Rio de Janeiro: Record, 2008. 
CANDIDO, A. A crônica. o gênero, sua fixação e suas transformações no Brasil. São Paulo: Unicamp, 1992.

COUTINHO, A. Ensaio e crônica. In: COUTINHO, A. (org.). A literatura no Brasil. v. 6. 5.ed. São Paulo: Global, 1999.

COUTINHO, A. A crônica de Rubem Braga: Os trópicos em palimpsesto. Signótica, v. 18, 2006.

LIMA, E. P. Páginas ampliadas - O livro reportagem como extensão do jornalismo e da literatura. São Paulo: Unicamp, [s/d]. (Coleção Momento).

MELO, J. M. A opinião no jornalismo brasileiro.

2.ed. Petrópolis: Vozes, 1994.

ROSSI, C. O que é jornalismo. 10.ed. São Paulo: Brasiliense, 1994.

SÁ, J. de. A crônica. São Paulo: Ática, 1999. 